\title{
Ethical and legal observations on contract cheating services as an agreement
}

\author{
Loreta Tauginiené* (iD and Vaidas Jurkevičius
}

\author{
* Correspondence: \\ loratauginiene@hotmail.com \\ Mykolas Romeris University, Ateities \\ str. 20, 08303 Vilnius, Lithuania
}

\begin{abstract}
In this paper we cast light on one form of dishonest behaviour in academia contract cheating services. We examine how an agreement between a student and a contract cheating services provider is viewed from ethical and legal perspectives. For this purpose we carried out an analysis of contract cheating services as an agreement which, in Lithuania, is currently facing the challenge of implementing laws regarding contract cheating services as a violation of academic ethics. Taking into consideration recent jurisprudence, together with social media articles, we conclude that while any agreement for contract cheating services is severely criticized in terms of ethics, the courts either do not regard this type of agreement as a violation of legal norms, or they inadequately apply legal remedies when such an agreement is deemed to be void.
\end{abstract}

Keywords: Contract cheating, Lawsuit, Case law, Ethical norms, Legal norms, Academia

\section{Introduction}

Forms of dishonest behaviour in academia are numerous and diverse (Chisholm, 1992; Gaižauskaitè and Tauginienè, 2017) and practised by both students and academics: among such forms of behaviour is contract cheating. In the literature, the term contract cheating is used interchangeably with such terms as essay mill, paper mill, ghostwriting, and unethical tutoring. The parallel of plagiarism and contract cheating is aligned because contract cheating is so-called "plagiarism via ghostwriting" (Curtis and Clare, 2017; Sivasubramaniam et al., 2016; Walker, 1998). However, we can point out some distinctions inherent in these terms: first, the terms appeared at different times. Hawley (1984) states that "plagiarism is perhaps as old as education itself" (p. 35) while contract cheating services date back to the 1960s (Dickerson, 2007). Second, both of them differ in the nature of their intent. It is said that "plagiarism usually occurs unintentionally, due to ignorance and lack of adequate referencing skills" (e.g. Girard, 2004 as quoted in Regmi, 2011: 77). Contract cheating, however, inherently concerns an intentional action to defraud (Dickerson, 2007; Draper et al., 2017; Hawley, 1984; Jones, 2008). Furthermore, plagiarism might be treated as copyright infringement and investigated under the copyright law (e.g. Billings, 2004; Hassett v. Hasselbeck et al. in 2009 - Enghagen, 2013; Saunders, 2010) while contract cheating, always seen as immoral, is difficult to prove, particularly in a court of law. It is also argued that "plagiarism is often not a truly legal issue" (Sonfield, 2014: 79), but rather a professional and

(c) The Author(s). 2017 Open Access This article is distributed under the terms of the Creative Commons Attribution 4.0 International License (http://creativecommons.org/licenses/by/4.0/), which permits unrestricted use, distribution, and reproduction in any medium, provided you give appropriate credit to the original author(s) and the source, provide a link to the Creative Commons license, and indicate if changes were made. 
moral issue described in university policy-related documents and managed accordingly (Nimmer, 2004; Sonfield, 2014; Stearns, 1992). It is obvious that plagiarism has a twofold character, legal and moral, while contract cheating is simply described as moral. In the light of these distinctions, we refer to the definition of contract cheating by Clarke and Lancaster (2006). Contract cheating is the violation of ethical norms by students within academia, i.e. when students strive for academic credits while engaging external assistance to gain an unfair advantage. Arguably, conclusion of an agreement between a student and a contract cheating services provider is assumed to be incompatible with ethical norms. However, in terms of law such an agreement appears not to be considered illegal. Ethics refers to behaviour which in the presence of malpractice forms the basis of legislation (Regmi, 2011). In the same vein, ethics encounters values unregulated by law (Jones, 2008; Riss, 2008 as quoted in Regmi, 2011), but related to legal principles applied by the courts which derive from ethical norms. However, there are cases when legal norms and their implementation are in conflict with ethical norms.

It appears that it is easier to prosecute contract cheating, once discovered, than it is to discover the transgression in the first place (Dawson and Sutherland-Smith, 2017). This seems so because substantiating "contract cheating to the extent required in formal university processes is very difficult" (Dawson and Sutherland-Smith, 2017, p. 7). This is to say that the identification of contract cheating services provider is possible when a student, caught in contract cheating, discloses the identity of contract cheating services provider. In such a case, the university can apply sanctions only on a student, but not on a contract cheating services provider. Hence, the university may request further investigations either by the ombudsman (if such exists at national level) or by the court. However, when a contract cheating services provider is disclosed, a successful prosecution is more likely because contract cheating services as an agreement might be assessed in legal terms (e.g. under the article regulating kinds of agreements and their terms). Following this, the paper aims to show how contract cheating services are and might be considered in terms of law and ethics as an agreement.

The organization of this paper begins with the literature review on contract cheating and contract cheating services in legal and ethical terms, and continues with an instance from Lithuanian case law by presenting a lawsuit between a (former) student and a company delivering contract cheating services. Ultimately, the paper ends with discussion and conclusions.

\section{Literature review}

\section{Contract cheating}

In the U.S. in the early 1970s many states passed laws prohibiting any entity from producing works and selling them to students (Dickerson, 2007). Despite this, the emerging gravity of this issue was predicted in the 1980s (Hawley, 1984) and many studies evidence the volume of contract cheating. The scientific literature traces the first court case in the U.S. described in a paper by Christopher S. Hawley in 1984. He analysed the case of State $v$. Saksniit which aimed to proscribe the functioning of the company Termpapers, Inc. This showed a clear judicial attitude to combatting plagiarism. Furthermore, the same case proved the intention of a student to deceive the university in the way the instructions about the paper were provided (Dickerson, 2007). 
All kinds of academic dishonesty are abundantly increasing (e.g. Jones, 2008; McCabe et al., 2001; Murdock and Anderman, 2006; Rigby et al., 2015; Simkin and McLeod, 2010). Curtis and Clare (2017) argue that contract cheating is declining due to increased detection tools and associated sanctioning, while prior studies (e.g. Jones, 2008; Rigby et al., 2015) claim the opposite. Hence, the literature on contract cheating related behaviour and awareness of contract cheating makes clear statements on this matter. Over $20 \%$ of university officials are aware of term paper companies operating on their campus (Einsiedler, 1972) while $10 \%$ of students knew who among them purchased term papers (Hawley, 1984). Statistics are eloquent when investigating how many students use the services of such companies, ranging from 5\% (Hawley, 1984; McCabe, 2005) to 7.9\% (Zafarghandi et al., 2012). Also, some studies show that students, once engaged in contract cheating, are prone to use it again (Clarke and Lancaster, 2006; Fida et al., 2016).

Many authors argue that the negative outcomes of contract cheating are egregious: the undermined validity of students' knowledge evaluation (Hawley, 1984; Magnus et al., 2002); demotivation to study honestly (Magnus et al., 2002); eventual harm to certain groups of people (e.g. patients) (Mazur, 1989); editors and reviewers (Wells and Farthing, 2008 as quoted in Regmi, 2011)); unmerited academic credits (Draper et al., 2017); devalued diplomas (Dickerson, 2007); loss of professional credibility (Billings, 2004); defrauding future employers (Crittenden et al., 2009; Dickerson, 2007); career disruption (Regmi, 2011); deprivation of fair competition (Billings, 2004; Magnus et al., 2002); and jeopardising public safety and community confidence in higher education (Bertram-Gallant, 2016; White, 2016). These outcomes are not exhaustive and may vary depending on the type of infringer, either student or academic.

The literature distinguishes three core approaches to addressing dishonesty, including contract cheating: "enforcement and punishment, education and clarification, and counselling and rehabilitation" (Chisholm, 1992: 267). The approach of enforcement and punishment falls under the deterrence theory. In order to inhibit the misbehaviour this theory suggests that alleged offenders must understand that they will be caught and their misbehaviour will attract penalties (Fida et al., 2016; McCabe and Treviño, 1993). This is to say that in the case of an ethics failure, there should be an appropriate establishment and enforcement of university rules and laws (Jones and McLellan, 2000 as quoted in Regmi, 2011) as it interconnects with professionalism (Bruhn et al., 2002). However, daily practices evidence that the university is not alone in the fight against contract cheating.

\section{Contract cheating services}

Contract cheating includes many actors that might be curbed by the law in the case of a breach - university, students, academics, people paying tuition fees (e.g. parents, prospective employers), ghostwriters, ghostwriters' employers, the leaseholder of the website domain that provides and/or advertises contract cheating services, etc. (Draper et al., 2017). As the literature testifies several cases on contract cheating from the university decision-making perspective (e.g. Berger and Berger, 1999; Billings, 2004; Mazur, 1989; McCabe, 2005; McCabe and Treviño, 1993), we will further examine ghostwriters' employers providing contract cheating services even though they claim the contrary; such companies do not perpetrate fraud, but facilitate fraud. In presence of a myriad of companies that provide legitimate consultancy or research services, presumably some or 
many of them indeed assist students with their assignments under allegedly consultancy or research services. So apparently the latter usually hardly operates within the terms of the law (Hawley, 1984), e.g. such companies fail to meet such criteria of social justice as proportionality, the principle of merit, and affected social groups (Sadurski, 1984). Hence, the distinction between social and legal justice should be clarified. Social justice is characterized as justice of outcomes (substantive justice) while legal justice is about procedures without reference to consequent outcomes (procedural justice) (Sadurski, 1984). When describing contract cheating services, it becomes clear that they face both social and legal justice through their operations. Apparently, such companies fall short in the moral character of their functioning (Dickerson, 2007; Sivasubramaniam et al., 2016). Moreover, when registering a company it is required that the business is lawful and moral (for example, in the UK); otherwise, the operation of a company whose economic activity is legal, but immoral, might be curtailed (Draper et al., 2017).

Contract cheating services are openly advertised on university campuses (e.g. Chisholm, 1992), on the internet (e.g. Bretag, 2017; Dickerson, 2007; Lancaster and Clarke, 2017; Wallace and Newton, 2014) and elsewhere, despite the fact that, for example, the misleading advertisement of services is regulated by law, e.g. in UK by the Fraud Act 2006 (Draper et al., 2017). Naturally, such practices had eventually to be curtailed. Yet, this is not a single practice related to contract cheating services. To demonstrate, we provide just a few examples to illustrate how contract cheating services were assessed in legal terms. In A.V. et al. v. iParadigms, $L L C$ (2008) case a company offering plagiarism detection services was alleged to be delivering contract cheating services. The court adjudged copying papers in the database of companies that deliver plagiarism detection service as a lawful fair use despite the fact that such companies are for-profit commercial organizations (Enghagen, 2013). As such an action was recognized as a lawful fair use due to its purpose to prevent plagiarism and protect authored papers from plagiarism, neither is there any copyright infringement. Another example refers to a lawsuit where a graduate student sued three term-paper websites (Dickerson, 2007). The student alleged that these websites sold her paper published on her blog without her permission, i.e. infringed her copyright. This lawsuit ended with a confidential settlement.

The ability of both university and student to take any action against such companies is limited (Draper et al., 2017). Although a student can be expelled for contract cheating (e.g. Curtis, 2003; Enghagen, 2013) and universities seem to handle misbehaviour appropriately, Billings (2004) argue that courts should not reconsider universities' decisions regarding academic malpractices, but rather review how the investigation was held from a procedural perspective. Relying on what has been described above in this paper we focus on two research questions - i) how case law considers contract cheating services as an agreement and ii) what consequences derive to the parties from contract cheating services as an agreement.

\section{Judicial system in Lithuania}

The judicial system in Lithuania consists of courts of general jurisdiction and courts of special jurisdiction. The Supreme Court of Lithuania, the Court of Appeal of Lithuania, regional courts and district courts belong to the category of courts of general jurisdiction dealing with civil and criminal cases, while the Supreme Administrative Court of 
Lithuania and regional administrative courts represent courts of special jurisdiction, dealing with disputes arising from administrative legal relations. The Special Chamber of Justices, established and operational in Lithuania to deal with jurisdiction-related issues, explained that university activities are not related to the exercise of public or internal administrative powers, but suppose the provision of public services, and therefore the university cannot be regarded as a public administration authority (Specialioji teisëjų kolegija, 2010). It also clarified that the university (including its rector) does not have a public administration mandate (Specialioji teisèju kolegija, 2011). All this implies that disputes arising from academic relations are attributable to courts of general jurisdiction. As a result, in Lithuania disputes related to contract cheating services as an agreement are dealt with in courts of general jurisdiction.

In this paper we will describe the jurisdiction of a district court, as we analysed their decisions that were not further appealed to superior courts. As it is stated in the (Law amending the Law on Courts of the Republic of Lithuania 1994), a district court is the first instance for criminal, civil cases and cases of administrative offences.

\section{Failure of contract cheating services}

To address our research questions, we describe an instance from Lithuanian case law by presenting a lawsuit between a (former) student as a client and a company delivering contract cheating services in the failure of their bilateral agreement. The first case resonated publicly in 2013 in the social media, though additionally, we analysed the anonymised the court decision retrieved from the publicly available Lithuanian courts' information system (LITEKO) and 4 related social media articles. The social media articles helped to enrich data collected by journalists, but not disclosed by the court decision. Afterwards, using the LITEKO search engine, we looked for related civil case law using such keywords as 'tyrimo darbo atlikimo sutartis' (research fulfilment contract) and 'konsultavimo sutartis' (consultancy contract). We found another three prior case law examples related to contract cheating services that we included in the analysis. In all four case law instances, a limited liability company Studium Generale was sued. Interestingly, the plaintiffs were three women (two of them had an educational background in law) and one man. Lastly, university documents concerning these cases are not publicly available - this is a limitation of our research.

Civil Cases I - R. K. v. Studium Generale and L. L. v. Studium Generale.

In the Marijampole Region District Court, the plaintiff being a law student, on the basis of a research fulfilment and consultancy contract, terminated a contract with the defendant due to uncompleted work. The plaintiff requested recovery of a pre-paid amount of 1300 LTL (376.51 EUR) from the defendant (Civil Case No. 2-322-802/ 2012). In this case, the defendant submitted his position stating that he had fulfilled his obligations to the plaintiff properly, but did not receive any payment. In the opinion of the defendant, the plaintiff submitted work to the university without the author's knowledge and consent; therefore, the plaintiff gained advantage from such submission and, consequently, it resulted in damages to the defendant. The court rejected those arguments of the defendant as unsubstantiated and upheld the plaintiff's claim. The court also ascertained that in such instances the general principle of law ex injuria jus non oritur (law does not arise from injustice) should be applied. Again, there is a clear 
conflict between ethics and law, when the activity is not evaluated ethically. This case was not a singular event. Previously a similar court decision was taken in the (Civil Case No. 2-3352-868/2012) L. L. v. Studium Generale. The court found that the obligations should be fulfilled in a fair, appropriate and timely manner; therefore, the plaintiff will get back a pre-paid amount of 1800 LTL (521.32 EUR) from the defendant. Such a conclusion implies the question of whether the principle of fairness, in general, can be applied to such obligations.

Civil Case II - D. B. v. Studium Generale.

In one more critically-assessed court decision, a compromise agreement was approved between a person who bought and one who sold a work (Civil Case No. 24442-862/2013). The District Court of Vilnius City resolved a dispute under the plaintiff's claim against the defendant for an amount of about 3400 LTL (984.71 EUR) paid under the research fulfilment contract, and adjudgment of the penalty and interest. The court upheld the plaintiff's claim. After evaluating the written evidence in the case, the court noted that "the compromise agreement submitted by the parties does not conflict with the imperative provisions of the law and the public interest, does not violate the rights of the third parties, there are no either other grounds or other circumstances for invalidating an agreement due to which the submitted compromise agreement cannot be approved" (Civil Case No. 2-4442-862/2013:1). Although such an agreement is manifestly null and void because it is contrary to public order and the well-meaning moral and imperative provisions of the law, the court decision to approve the compromise agreement is questionable. Again, neither the activity of the company nor the student's activity has been appraised ethically.

Civil Case III - G. K. v. Studium Generale.

The District Court of Vilnius City examined a Civil Case (Civil Case No. 2-3992-905/ 2013) in which the student, as a plaintiff, requested to adjudge from the company, which wrote a work (as the defendant), the amount of 1500 LTL (434.43 EUR) due to the nonaccomplishment of the contract, and the amount of 1500 LTL (434.43 EUR) as nonpecuniary detriment. The student indicated that in the research fulfilment and consultancy the defendant committed to carry out a 60-page research work. According to the student, the defendant did not fulfil the contractual obligations, i.e. he did not accomplish the work, did not consult and did not follow the agreed timelines. The student asserted that the defendant sent him part of the work (34 pages) by e-mail which later, in the opinion of the plaintiff, simply "turned red from comments of the supervisor" (Civil Case No. 2-3992-905/2013:1). According to the plaintiff, after the termination of the contract, the defendant mocked him, i.e. the plaintiff suffered from psychological shock, did not complete the work in time and could not defend it. The university expelled the plaintiff, a law student, at his own request. The court found that such an agreement and the consequent actions were in conflict with the moral and ethical obligations of the student, enshrined in the university code of ethics; therefore, the court decided to apply the consequences of a null and void agreement - a bilateral restitution - and adjudge to the student the pre-paid amount of 1500 LTL from the defendant under a void agreement. Consequently, the plaintiff had to return the work to the defendant and transferred rights to the work. In this case, the court, first of all, referred to the norms of the Civil Code of the Republic of Lithuania that determines that an agreement contrary to the imperative norms of the law and to public order or a well-meaning moral is null and void. 
Analysing this case, we notice two sides of a coin. On the one hand, the court expressis verbis relied on the university code of ethics and based its decision precisely as a breach of ethical rules, accordingly as a basis for the invalidity of the contract between the parties. On the other hand, the legal doctrine states that in such a case restitution could not be applied at all because both parties were aware that such an agreement was contrary to the public order or moral good (Jurkevičius, 2012). In other words, the application of restitution is shady. Nevertheless, after passing this decision, the court forwarded the collected material to the pre-trial investigation institutions regarding the assessment of the legality of the company's activity, i.e. to potentially impose criminal liability on the company.

\section{Discussion}

Despite all efforts and legal failures to curtail companies' operations associated with contract cheating, a university is seen as the core institution that should take responsibility in this regard (Dickerson, 2007; Hawley, 1984), particularly in the proper handling of allegations (Mazur, 1989), in teaching how to deal with ethical issues in the labour market, and leading in an ethical manner (Treviño and Nelson, 2011). However, there are also many malpractices, among which is contract cheating, that are, unfortunately, beyond the control of universities. Hence, universities' endeavours and court practices have room to maintain the balance of justice at least in some way. From the cases analysed it is evident that court decisions, even three out of four taken by the same court, are diverse and upheld the lawsuit of the plaintiff. The courts' decisions are not always congruent with legal norms due to scarce regulation, and in some cases ethical norms are given priority in such decisions (e.g. Tauginienè and Jurkevičius, 2017). Rules of the Civil Code of the Republic of Lithuania that anticipate the contract as null due to the discrepancy to public order or bona fide ought to be applied unambiguously in the mentioned cases, particularly when there is potential complicity. The cases analysed resemble the conspiracy described by Jones (2008) that occurred between the plaintiff and defendant (Civil Case II).

In the Civil Case I, an oxymoron is apparent regarding the application of the principle of fairness. Although the contract cheating services are unfair because of their nature, the obligation to pursue an agreement ought to be fair. Obviously, fairness as an ethical principle is interpreted two-sidedly. The court hesitated to make an explicit decision regarding contract cheating services, hence showing the failure of the appropriate application of the principle of fairness in legal doctrine. In other words, ethical and legal norms are in conflict. Estimating fairness requires sensitivity (Newey, 2016). Furthermore, the court was too formal when estimating a self-evident relationship of the parties in that a student had no intention to submit a paper to the university as his own, or to deceive the university by concluding the research fulfilment and/or consultancy contract. The latest court decision seems promising due to the possibility to declare the contract null (Civil Case III); therefore, it is very likely that the coherence in court decisions will further support avoiding mistakes in applying legal norms, and losses for contract cheating services will discourage their providers from continuing in the same vein.

Although Dawson and Sutherland-Smith (2017) assert that the detection of contract cheating is less successful than the prosecution of contract cheating, Draper et al. 
(2017) point out that lawsuits on contract cheating cannot be more successful either in coping with contract cheating. This is to say that after expelling a student due to contract cheating to which he/she confessed, the university did not always have the standing to sue the provider of contract cheating services. In such cases, the prosecutor's office is able to defend the public interest. For example, in Lithuania, the contract cheating was seen as a violation of purely ethical standards, for which only academic sanctions could be imposed (such as a prohibition on defending the final paper, a negative evaluation of it, or even a student's expulsion from a university), but such actions have not been deemed to be a legal violation for which legal sanctions are applicable. The writing of a work and consulting were considered to be legitimate economic activities. In practice, the prosecutor's office usually reasons that the scale of purported harm is of low priority, has no immediate gain (Draper et al., 2017) and is unworthy of public expenditure (Dickerson, 2007); therefore, the prosecutor's office finds no purpose in taking any action against the enterprise. Furthermore, in Lithuania, when establishing a private legal entity there is no requirement to indicate economic activities to be carried out in the constitution, i.e. activities are not listed in accordance with the classification of economic activities. As a result, a company set up for the purpose of performing activities related to writing services can be registered, unless it publicly declared such operations, which would not look very credible. Still, after establishing that a company delivers contract cheating services, the public prosecutor as guardian of the public interest could initiate the liquidation of such a business. Although there are few legal norms related to academic integrity, they can play a key role in harnessing contract cheating services. However, giving a character to contract cheating services as a violation of ethical, not legal norms is undeveloped. This is to say that law enforcement institutions and academic institutions are disproportionally empowered in fighting against contract cheating.

As a consequence of these cases, a new legal norm on contract cheating (specifically when it is paid) was introduced, coming into force on 1 January 2017. This norm took the character of a disciplinary norm carrying sanctions ranging from 150 EUR to 3000 EUR only for final papers (Lietuvos Respublikos administracinių nusižengimų kodeksas, 2015). So far there is no case law based on this norm, but it is supposed to function as a means to deter students from contract cheating. Furthermore, while prostitution as such is prohibited from advertising in some countries (including Lithuania), to constrain legal advertising by companies that allure students without scruples to use their services to deceive a university is unsuccessful - precisely as Dickerson (2007) addressed this issue as well.

\section{Conclusions}

While the cases described do not depict a trend, they do demonstrate a positive perspective in tackling providers of contract cheating services through legal measures, by financial penalty (e.g. in the case of such agreements payments should not be made to any of the parties concerned, but to the state budget; this would require new legal provisions), prohibiting advertising, or using other legal remedies in tandem.

The courts are facilitators for universities to solve academic issues, particularly in contract cheating. While they manage to identify contract cheating services as an illegal activity, they still lack the application of proper legal remedies. Hence, it is important for the courts to determine how to detect the true purpose of an agreement of 
whatever type (e.g. the intent of the party to deceive is apparent when the title or the topic of a bespoke paper is explicitly indicated in a provision of the agreement). Having such detection tool would improve prospective case law. In addition, the courts could refer to ethical norms expressed in various university documents (e.g. code of ethics) as well as to substantial foreign case law in the field.

Legal norms are not always in balance with ethical norms, owing to the debate over who has the responsibility to investigate behaviour relating to academic integrity. Universities should take the first step in detecting and investigating contract cheating in terms of possible sanctions for a student. Such evidence should be further examined by the courts in order to deem such an agreement as void, and to apply appropriate legal remedies for both parties.

Acknowledgements

For providing comments on the manuscript, we thank reviewers for their valuable comments for improvement of this paper.

Authors' contributions

LT is Researcher of Ethics Management in Academic Ethics Centre Mykolas Romeris University. She analysed the literature, designed an empirical research methodologically, analysed social media articles and wrote the manuscript. VJ is a Lecturer in the Faculty of Law Mykolas Romeris University and Attorney-at-law at the law firm "Sinkevičius and Partners". He analysed case law and wrote the manuscript. Both authors read and approved the final manuscript.

Funding

No funding was received.

Competing interests

The authors declare that they have no competing interests.

\section{Publisher's Note}

Springer Nature remains neutral with regard to jurisdictional claims in published maps and institutional affiliations.

Received: 11 August 2017 Accepted: 31 October 2017

Published online: 21 November 2017

References

Berger CJ, Berger V (1999) Academic discipline: a guide to fair process for the university student. Columbia Law Review 99(2):289-364

Bertram-Gallant T (2016) Response to White's 'Shadow Scholars and the Rise of the Dissertation Service Industry'. J Res Pract 12(1):Article V2

Billings R (2004) Plagiarism in academia and beyond: what is the role of the courts? Univ San Franc Law Rev 38:391-429

Bretag T (2017) Evidence-Based Responses to Contract Cheating. In: Conference Proceedings of the Plagiarism across Europe and Beyond 2017, Mendel University in Brno, Brno, 24-26 may 2017. P 9. https://plagiarism.pefka.mendelu. cz/files/proceedings17.pdf. Accessed 16 June 2017

Bruhn JG, Zajac G, Al-Kazemi AA, Prescott LD (2002) Moral positions and academic conduct: parameters of tolerance for ethics failure. J Higher Educ 73(4):461-493

Chisholm D (1992) An epidemic of cheating? Political science and. Politics 25(2):264-272

Civil Case No. 2-322-802/2012. 2012. Marijampolès rajono apylinkès teismo m. vasario $21 \mathrm{~d}$. sprendimas. http://liteko. teismai.It/viesasprendimupaieska/tekstas.aspx?id=922d78c6-84eb-4e66-8a51-8000065e436a. Accessed 21 July 2017

Civil Case No. 2-3352-868/2012. 2012. Vilniaus miesto 3 apylinkès teismo m. rugpjūčio 13 d. sprendimas. http://liteko. teismai.lt/viesasprendimupaieska/tekstas.aspx?id=88ebe07f-bd56-46e0-8a42-f61e925706e6. Accessed 21 July 2017

Civil Case No. 2-3992-905/2013. 2013. Vilniaus miesto 3 apylinkès teismo m. kovo 20 d. sprendimas. http://liteko.teismai. It/viesasprendimupaieska/tekstas.aspx?id=d2d4cb63-da15-4d1b-9e86-2de88bb011af. Accessed 21 July 2017

Civil Case No. 2-4442-862/2013. 2013. Vilniaus miesto 3 apylinkès teismo m. sausio 25 d. sprendimas. http://liteko. teismai.It/viesasprendimupaieska/tekstas.aspx?id=1fbfa4be-c269-46b3-a6e3-0a77c6968908. Accessed 21 July 2017.

Clarke R, Lancaster T (2006) Eliminating the successor to plagiarism: identifying the usage of contract cheating sites. Proceedings of the International Integrity \& Plagiarism Conference, In http://www.plagiarism.org/assets/Clarke2_ fullpaper2006.pdf. Accessed 25 July 2017

Crittenden VL, Hanna RC, Peterson RA (2009) The cheating culture: a global societal phenomenon. Business Horizons 52:337-346

Curtis GJ, Clare J (2017) How prevalent is contract cheating and to what extent are students repeat offenders? Journal of Academic Ethics 15:115-124

Curtis P (2003) Cheating MBA student faces course expulsion. In: The Guardian, 24 July 2003. https://www.theguardian. com/education/2003/jul/24/highereducation.uk1. Accessed 16 June 2017

Dawson P. Sutherland-Smith W (2017) Can markers detect contract cheating? Results from a pilot study. Assess Eval Higher Educ. https://doi.org/10.1080/02602938.2017.1336746 
Dickerson D (2007) Facilitated plagiarism: the Saga of term-paper Mills and the failure of legislation and litigation to control them. Villanova Law Review 52(1):21-66

Draper MJ, Ibezim V, Newton PM (2017) Are essay Mills committing fraud? An analysis of their behaviours vs the 2006 fraud act (UK). Int J Educ Integr 13(3). https://doi.org/10.1007/s40979-017-0014-5.

Einsiedler E (1972) Buying term papers. Today's. Education 61(6):44-46

Enghagen LK (2013) Plagiarism: intellectual dishonesty, violation of law, or both? J Hospitality Tourism Educ 23(1):28-35

Fida R, Tramontano C, Paciello M, Ghezzi V, Barbaranelli C (2016) Understanding the interplay among regulatory selfefficacy, moral disengagement, and academic cheating behaviour during vocational education: a three-wave study. J Bus Ethics. https://doi.org/10.1007/s10551-016-3373-6

Gaižauskaite I, Tauginiene L (2017) The maze of definitions on academic integrity and related terms - is it easy to apply in practice? In: Conference Proceedings of 9th International Conference on Education and New Learning Technologies, Barcelona, 3-5 July 2017. P. 7840-7844.

Girard N (2004) Plagiarism: an ethical problem in the writing world. Association of Perioperative Registered Nurses. Journal 80:13-15

Hawley CS (1984) The thieves of academe: plagiarism in the university system. Improv Coll Univ Teach 32(1):35-39

Jones AH, McLellan F (2000) Ethics in biomedical publication. John Hopkins University, Baltimore

Jones M (2008) Essays for sale: time for legal regulation? Proceedings of the International Integrity \& Plagiarism Conference, In http://www.plagiarism.org/assets/Jones2008_fullpaper\%20(1).pdf. Accessed 23 July 2017

Jurkevičius V (2012) Teisinè atsakomybè. In: Mitkus S, Bublienè R, Cibulskienè R, Jakaitis S, Jurkevičius V, Keršulienè V Matulienè J, Nedzinskaitè V, Radzevičius E, Romaškevičienė D, Šinkūnas H, Rutkauskas A, Trinkūnienè E, Varno R (eds) Teisés pagrindai. Technika, Vilnius

Lancaster T, Clarke R (2017) Rethinking Assessment by Examination in the Age of Contract Cheating. In: Conference Proceedings of the Plagiarism across Europe and Beyond 2017, Mendel University in Brno, Brno, 24-26 May 2017. P. 215-228. https://plagiarism.pefka.mendelu.cz/files/proceedings17.pdf. Accessed 16 June 2017

Law amending the Law on Courts of the Republic of Lithuania (1994). Unofficial translation. http://www.teismai.lt/data/ public/uploads/2014/12/republic-of-lithuania-law-amending-the-law-on-courts.doc. Accessed 4 October 2017

Lietuvos Respublikos administraciniu nusižengimų kodeksas (2015) Teisės aktų registras 2015-11216. https://www.e-tar. It/portal//t/legalAct/4ebe66c0262311e5bf92d6af3f6a2e8b. Accessed 12 July 2017

Magnus JR, Polterovich VM, Danilov DL, Savvateev AV (2002) Tolerance of cheating: an analysis across countries. J Econ Educ 33(2):125-135

Mazur A (1989) Allegations of dishonesty in research and their treatment by American universities. Minerva 27:177-194

McCabe DL (2005) Cheating among college and university students: a north American perspective. Int J Educ Integr 1(1). 10.21913/JEl.v111.14.

McCabe DL, Treviño LK (1993) Academic dishonesty: honor codes and other contextual influences. J Higher Educ 64(5):522-538

McCabe DL, Treviño LK, Butterfield KD (2001) Cheating in academic institutions: a decade of research. Ethics \& Behavior 11(3):219-232

Murdock TB, Anderman EM (2006) Motivational perspectives on student cheating: toward an integrated model of academic dishonesty. Educ Psychol 41(3):129-145

Newey CA (2016) Fairness as "appropriate impartiality" and the problem of the self-serving bias. Ethical Theory Moral Pract 19(3):695-709

Nimmer D (2004) The moral imperative against academic plagiarism (without a moral right against reverse passing off). DePaul Law Review 54(1):1-77

Regmi K (2011) Ethical and legal issues in publication and dissemination of scholarly knowledge: a summary of the published evidence. J Acad Ethics 9:71-81

Rigby D, Burton M, Balcombe K, Bateman I, Mulatu A (2015) Contract cheating \& the market in essays. J Econ Behav Organ 111:23-37

Riss P (2008) The concept of scientific dishonesty: ethics, value, systems, research. In: Wells F, Farthing M (eds) Fraud and misconduct in biomedical research, Royal Society of Medicine, London

Sadurski W (1984) Social justice and legal justice. Law Philos 3(3):329-354

Saunders J (2010) Plagiarism and the law. Learned Publishing 23(4):279-292

Simkin MG, McLeod A (2010) Why do College students cheat? J Bus Ethics 94(3):441-453

Sivasubramaniam S, Kostelidou K, Ramachandran S (2016) A close encounter with ghost-writers: an initial exploration study on background, strategies and attitudes of independent essay providers. Int J Educ Integrity 12(1). https:// doi.org/10.1007/s40979-016-0007-9

Sonfield MC (2014) Academic plagiarism at the faculty level: legal versus ethical issues and a case study. J Acad Ethics 12:75-87

Specialiosios teisejjų kolegijos 2010 m. vasario 9 d. nutartis byloje K.S. v. Vilniaus Gedimino technikos universitetas. http:/liteko. teismail.t/viesasprendimupaieska/tekstas.aspx?id=33107574-dc9d-4cf8-aaba-a6efc7d17137. Accessed 4 October 2017

Specialiosios teisejju kolegijos 2011 m. liepos 4 d. nutartis byloje A.M. v. Mykolo Romerio universitetas. http://liteko.teismai.lt/ viesasprendimupaieska/tekstas.aspx?id=6212a729-756e-4353-bbe9-80e9ce293bbb. Accessed 4 October 2017

Stearns L (1992) Copy wrong: plagiarism, process, property, and the law. California Law Rev 80(2):1-34

Tauginiene $L$, Jurkevičius $V(2017)$ Incongruences of ethical and legal norms in academia: the case on revocation of doctoral degrees. J Acad Ethics 15(1):73-91

Treviño LK, Nelson KA (2011) Managing business ethics: straight talk about how to do it right, 5th edn. Wiley, New York Walker J (1998) Student plagiarism in universities: what are we doing about it? Higher Educ Res Dev 17(1):90-106

Wallace MJ, Newton PM (2014) Turnaround time and market capacity in contract cheating. Educ Stud 40(2):233-236

Wells F, Farthing M (2008) Fraud and misconduct in biomedical research. Royal Society of Medicine, London

White J (2016) Shadow scholars and the rise of the dissertation service industry: Can we maintain academic integrity? Journal of Research Practice 12(1):Article V1

Zafarghandi AM, Khoshroo F, Barkat B (2012) An investigation of Iranian EFL masters students' perceptions of plagiarism. Int J Educ Integr 8(2):69-85 